Acta Universitatis Wratislaviensis • No 3869

Literatura i Kultura Popularna XXIV, Wrocław 2018

DOI: $10.19195 / 0867-7441.24 .6$

\title{
Jana Dudková
}

ORCID: 0000-0002-3059-3711

Slovak Academy of Sciences

\section{"Cool XXL": Slovak millennial films in the context of postsocialist sensibility (of Slovak cinema)}

Keywords: Slovak cinema, postsocialism, anaesthetics, social drama, festival film, Carthesian perspective

Słowa kluczowe: kino słowackie, postsocjalizm, anestetyka, dramat społeczny, kino festiwalowe, Kartezjańska perspektywa

\section{“Cool" urban lifestyle}

The title of this paper is inspired by an eponymous review of one Slovak millennial film. ${ }^{1}$ Entitled simply as "Cool XXL", the review was written in 2003 by Martin Šmatlák, a film historian and back then also a critic, who concluded it with a highly symptomatic attempt to define the Slovak millennial sensibility of "coolness": "CCool' means not only cold or chilly, but also calm or indifferent. It is in this very aspect that this film [It Will Stay Between $U_{s}$ ] is so absolutely insurmountable. [...] It is so deeply preoccupied with itself that it does not establish any relationships. It is so deprived of emotions that it's being heartless. It creates a reality without facts, stories or interpretations. It is a sign without meaning, a scaffolding without a building, a 90-minute 'video clip'. It is so detached from life that it is completely lifeless. It is 'cool XXL"."2 There would be nothing special about this review, if Martin Šmatlák (in this case signed simply as a "film critic") had not been significantly involved in the process of the re-establishment of what

${ }^{1}$ Namely, Zostane to medzi nami (It Will Stay Between Us, dir. Miroslav Šindelka, 2003).

2 M. Šmatlák, "Cool XXL”, Domino forum 42, 2003, p. 26. All cited fragments were translated from Slovak by the author. 
we can (following Pierre Bourdieu's terminology) call the Slovak "film field" a "structured social space", featuring a distinctive set of power relationships in the cinematic area, defined not only by activities of the artists and people directly involved in film production, distribution, or reception, but also by activities of film critics, cultural politicians, and more generally by various political, institutional and industrial power relations. ${ }^{3}$

Šmatlák's review was published in one of the most important opposition magazines, established in 1991, the weekly Domino forum. Its author was not a full-time professional film critic, since the 1990s brought not only a crisis of Slovak cinema but also a radical transformation of film criticism, leaving it balancing mostly between the praxis of journalists guided by specific policies of their periodicals, and the praxis of experts writing reviews only occasionally. During the 1990s, Martin Šmatlák acted as a film scholar, dramaturgist (e.g. collaborating on Štefan Semjan's debut Na krásnom modrom Dunaji [On the Beautiful Blue Danube, 1994]), and lecturer at the Academy of Performing Arts in Bratislava, the first and biggest film educational institution in the country which even perceived itself as important political opposition to Vladimír Mečiar's authoritative regime.

What is even more important, Šmatlák also gradually became a highly competent cultural diplomat who, at the end of the first decade of the new millennium, was instrumental in creating the conditions for a restart of the almost completely devastated national cinema. Since the establishment of the Slovak Audiovisual Fund (Audiovizuálny fond, hereafter AVF) in 2009, Šmatlák has been its director and one of the key people responsible for AVF becoming the first institution that succeeded in providing systemic support for Slovak cinema in a wide range of activities, from supporting the development, production and distribution of films, to contributing to the digitalisation of cinemas, administering editorial and research activities, as well as co-financing festivals, workshops and film events. With the establishment of the AVF, national film production experienced significant quantitative growth from the yearly production of 2-4 feature-length films (in the period 1992-2002) to a relatively stabilised amount of more than 20 films (2012-2017), twice as much as during late socialism. The fund also fostered Slovak cinema's competitiveness in the home market as well as at foreign festivals, and contributed to the diversity of its genres.

However, as Šmatlák himself likes to stress, ${ }^{4}$ the importance of the establishment of the AVF also lies in its relative independence from the decision-making power of the state and its ministers. The AVF was imagined as an institution, the idea and philosophy of which is based on the ability of the film professionals and

3 "A field is a structured social space, a field of forces, a force field. It contains people who dominate and others who are dominated. Constant, permanent relationships of inequality operate inside this space" - P. Bourdieu, On Television, New York 1998, p. 40.

${ }^{4}$ For example, in a radio discussion Večer na tému: Slovenský film [Evening Topic: Slovak Cinema], 5 April 2017, Rádio Devín. 
film experts themselves to make decisions about supporting particular projects in a relatively independent way. ${ }^{5}$ The expert committees are not fixed and Šmatlák used to distance himself from the fund's direct dramaturgical ambitions. Nevertheless, there is something that could be called a hidden dramaturgy of the Slovak cinema that lies in the background of this paper. Thus, I would like to examine how the Slovak cinema's development before and after the establishment of the AVF was actually subject to specific social representations. And how many of them were actually adapted into the value system of its director. The notion of social representations as determined by the social psychologist Serge Moscovici ${ }^{6}$ is very helpful here, since it refers both to the process of conventionalisation and codification (i.e. of "objects, persons and events we experience"), and to the prescriptiveness of "values, ideas and practices" they represent. In short, social representations shared among a certain community influence us even before we start to think. ${ }^{7}$

Šmatlák's 2003 review entitled "Cool XXL" evaluates one of the films that form a trend labelled by Šmatlák himself, several years later, as the "urban lifestyle film". The term itself was coined by a critic and pop-culture theorist Juraj Malíček. Once again, this wasn't determined in a scholarly paper but in a review of one of the millennial lifestyle films, Katarína Šulajová's debut $O$ dve slabiky pozadu (Two Syllables Behind, 2004). After Martin Šmatlák adopted the phrase while looking back upon the 15 years of "independent" Slovak cinema in $2008,{ }^{8}$ it eventually became common in the works of various film historians. ${ }^{9}$ According to Šmatlák, this type of film "does not attempt to portray either the contemporary or the historic social context," emphasizing "'music-video-style' or visually seg-

${ }^{5}$ See also M. Šmatlák, "The Slovak Audiovisual Fund: A brief history of prolonged time," [in:] Transformation Processes in Post-Socialist Screen Media, eds. J. Dudková, K. Mišíková, Bratislava 2016, p. 16. For more about the history of the idea of the fund and its final foundation in 2009, see the whole of Šmatlák's scholarly paper (ibid., pp. 11-20).

${ }^{6}$ According to Moscovici, social representation is a "system of values, ideas and practices with a twofold function; first, to establish an order which will enable individuals to orient themselves in their material and social world and to master it; and secondly to enable communication to take place among the members of a community by providing them with a code for social exchange and a code for naming and classifying unambiguously the various aspects of their world and their individual and group history" - S. Moscovici, "Foreword", [in:] Health and Illness: A Social Psychological Analysis, ed. C. Herzlich, Oxford 1973, p. XIII. I wish to thank Marek Urban and his dissertation about social representations of Slovak cinema in discourse of film professionals for bringing my attention to this term, see M. Urban, Sociálne reprezentácie v diskurze slovenských filmových profesionálov v rokoch 2012-2014 (unpublished dissertation: Univerzita Konštantína Filozofa v Nitre, 2016).

${ }^{7}$ S. Moscovici, "The phenomenon of social representations", [in:] Social Representations: Explorations in Social Psychology, ed. G. Duveen, New York 2001, pp. 22-23.

${ }^{8}$ M. Šmatlák, "Hl'adanie vlastnej cesty", Kino-Ikon 1, 2008, pp. 135-147.

${ }^{9}$ See, e.g., J. Dudková, Slovenský film v ére transkulturality, Bratislava 2011; or K. Mišíková, "The real story: Indexing strategies of Slovak social film dramas", [in:] Transformation Processes in Post-Socialist Screen Media, eds. J. Dudková, K. Mišíková, Bratislava 2016, pp. 60-76. 
mented storytelling, as well as several other external characteristics of the contemporary world, such as cars and drugs, businessmen and bars, ubiquitous telly, dubbing or intrusive adverts, well-known city figures, socialites, petty celebrities and local wannabes". ${ }^{10}$

It is already clear enough that in Šmatlák's own evaluations of the trend, one theme stands out: theme of detachment from life. "It is so detached from life that it is utterly lifeless", he writes in 2003, while reviewing a current urban film release, It Will Stay Between Us. The same theme of detaching from life can also be found in Malíček's review of Two Syllables Behind, this time without negative connotations. Malíček writes: "Generational urban lifestyle cinema is not yet a clearly distinguishable film genre; rather, it relates to the trend of contemporary world cinema that is trying to put its finger on the pulse of the era without actually taking the pulse. [...] What is important is [its] spectacular, illustrative descriptiveness [...]. We do not see it as authentic and believable, but as rather decorative. It is pleasant to look at, nothing more - but even this is quite enough". ${ }^{11}$

Malíček admits that "in this kind of movies, the form is dominant", but he doesn't judge this, stressing their status of, as he calls it, "home-made pop" a certain form of "adaptation [of popular Western patterns] to domestic needs". ${ }^{12}$ Malíček also believes the film he is reviewing is able to fuel film-goers' interest in national cinema, which the domestic audience is not used to anymore (i.e. in the first two decades after the fall of communism). On the contrary, texts by Martin Šmatlák correspond with the fact that urban lifestyle cinema was mostly perceived as a failure among the film critics, both with regard to their "creative" or "artistic" values and with regard to audience attendance in cinemas. ${ }^{13}$ In addition, many journalists used to point out their ignorance of the problems of the audience outside of Slovakia's capital, Bratislava. ${ }^{14}$

Being rejected by most of the critics and without the support of audience interest, the trend of urban lifestyle cinema seemed to basically disappear even before the establishment of the AVF. Nevertheless, some of its characteristics, especially its emphasis on the shallowness of hypermodern life and its advertising aesthetics is still to be found in some of the biggest achievements of AVF funding, for example, the political thriller Kandidát (Candidate, dir. Jonáš Karásek, 2013). We might almost be tempted to think that, while negatively evaluating millennial urban films, Martin Šmatlák was wrong. In reality, though, Candidate

${ }^{10}$ M. Šmatlák, "Hl'adanie vlastnej cesty", p. 145.

11 J. Malíček, "Pop po domácky", Slovo 9, 2004, p. 16.

12 Ibid.

13 This is quite a paradox since the attendance numbers between distinctive urban lifestyle films are quite comparable with numbers achieved in domestic cinemas by Šlík's films or current social dramas. See Table 1.

${ }^{14}$ See, e.g.: D. Kacarová, "V kríze sú tvorcovia, nie slovenský film”, Národná obroda 32, 2005, p. 13. 
is not "empty" in the sense of social representations of emptiness of Slovak millennial films. It is not "empty" since it overcomes two important shortcomings of the abovementioned trend, as identified by Šmatlák, namely a departure from presenting the political and social situation, and renouncing audience interest. ${ }^{15}$ Candidate became one of the biggest successes with the audience of its time (see Table 1), and with its theme of eavesdropping and manipulations of presidential elections, it even anticipated some of the upcoming Slovak political events (e.g. an eponymous book ${ }^{16}$ describes events similar to the 2012 Gorilla wiretapping scandal, while the film about electing an unknown man for president preceded presidential elections in March 2014 with a non-politician winner Andrej Kiska).

Table 1. Attendance at Slovak urban lifestyle films and social dramas 2001-2016 $6^{17}$

\begin{tabular}{|c|c|c|c|c|}
\hline Title of the film & $\begin{array}{c}\text { Date } \\
\text { of premiere }\end{array}$ & $\begin{array}{c}\text { Number } \\
\text { of cinema-goers } \\
\text { in the year } \\
\text { of release }\end{array}$ & $\begin{array}{l}\text { Average number } \\
\text { of cinema-goers } \\
\text { per film show }\end{array}$ & $\begin{array}{c}\text { Genre/ "type" } \\
\text { of film }\end{array}$ \\
\hline Truth or Dare & 14.06 .2001 & 21,952 & unknown data & $\begin{array}{c}\text { urban lifestyle } \\
\text { film }\end{array}$ \\
\hline $\begin{array}{l}\text { Hannah and } \\
\text { Her Brothers }\end{array}$ & 11.01 .2001 & unknown data & unknown data & $\begin{array}{c}\text { urban lifestyle } \\
\text { film }\end{array}$ \\
\hline $\begin{array}{l}\text { It Will Stay } \\
\text { Between Us }\end{array}$ & 9.10 .2003 & 4,100 & 27.3 & $\begin{array}{c}\text { urban lifestyle } \\
\text { film }\end{array}$ \\
\hline $\begin{array}{c}\text { Two Syllables } \\
\text { Behind }\end{array}$ & 10.02 .2005 & 8,060 & 19.28 & $\begin{array}{c}\text { urban lifestyle } \\
\text { film }\end{array}$ \\
\hline $\begin{array}{c}\text { The City of the } \\
\text { Sun }\end{array}$ & 19.04 .2005 & 6,695 & 18.8 & social drama \\
\hline Half-Life & 6.12 .2007 & 12,757 & 19.28 & $\begin{array}{c}\text { urban lifestyle } \\
\text { film }\end{array}$ \\
\hline Big Respect & 5.03 .2009 & 2,070 & 8.63 & $\begin{array}{l}\text { urban lifestyle } \\
\text { film }\end{array}$ \\
\hline $\begin{array}{l}\text { BRATISLAVA- } \\
\quad \text { film }\end{array}$ & 30.07 .2009 & 238,581 & 63.24 & $\begin{array}{c}\text { urban lifestyle } \\
\text { film }\end{array}$ \\
\hline
\end{tabular}

15 On the other hand, the "emptiness" of current hits like V̌̌etko alebo nič (All or Nothing, dir. Marta Ferencová, 2017) is balanced by popularity of their genres, in this case of romantic comedy, and by their audience attendance numbers: during the opening weekend, for example, All or Nothing already had 68,352 movie-goers, which appeared as the biggest number in the history of Slovak postsocialist cinema.

16 M. Hečko, M. Havran, Kandidát. Denníky z odpočúvania, Bratislava 2012.

17 Data for the years 2001-2002: private communication with Miroslav Ulman from the Slovak Film Institute (e-mail from 6.07.2017). Data for the years 2003-2016: Reports on the Slovak Audiovisual Situation (published yearly by Media Desk Slovakia 2004-2013 and by Creative Europe Desk Slovakia 2014-2017). See http://www.cedslovakia.eu/clanky/sprava-o-staveslovenskej-audiovizie-v-roku (accessed: 5.12.2017). The genre classification is only approximate, it was derived by the author for the purposes of this text. 


\begin{tabular}{|c|c|c|c|c|}
\hline Foxes & 17.09.2009 & 2,270 & 16.11 & social drama \\
\hline $\begin{array}{c}\text { Heaven, Hell... } \\
\text { Earth }\end{array}$ & 16.04 .2009 & 13,808 & 20.37 & $\begin{array}{l}\text { urban lifestyle } \\
\text { film }\end{array}$ \\
\hline $\begin{array}{c}\text { Mosquitoes' } \\
\text { Tango }\end{array}$ & 22.01 .2009 & 40,613 & 46.68 & $\begin{array}{l}\text { urban lifestyle } \\
\text { film }\end{array}$ \\
\hline $\begin{array}{c}\text { My Husband's } \\
\text { Women }\end{array}$ & 25.06 .2009 & 12,274 & 23.03 & $\begin{array}{l}\text { urban lifestyle } \\
\text { film }\end{array}$ \\
\hline Gypsy & 14.07.2011 & 30,138 & 39.55 & social drama \\
\hline The House & 29.09 .2011 & 5,442 & 14.95 & social drama \\
\hline Lóve & 13.10 .2011 & 113,000 & 53.89 & $\begin{array}{c}\text { urban lifestyle } \\
\text { film }\end{array}$ \\
\hline Made in Ash & 13.09 .2012 & 2,409 & 36.50 & social drama \\
\hline $\begin{array}{c}\text { Tigers in the } \\
\text { City }\end{array}$ & 7.06 .2012 & 7,420 & 21.08 & $\begin{array}{l}\text { urban lifestyle } \\
\text { film }\end{array}$ \\
\hline Fine, Thanks & 31.01 .2013 & 1,649 & 16.17 & social drama \\
\hline Candidate & 10.10 .2013 & 80,234 & 52.86 & $\begin{array}{l}\text { political thriller } \\
\text { (with elements } \\
\text { of the urban } \\
\text { lifestyle) }\end{array}$ \\
\hline My Dog Killer & 21.03 .2013 & 5,191 & 27.97 & social drama \\
\hline The Miracle & 5.09 .2013 & 5,135 & 21.67 & social drama \\
\hline Children & 25.09 .2014 & 2,731 & 32.13 & social drama \\
\hline Indian Summer & 31.10 .2013 & 3,329 & 22.57 & $\begin{array}{l}\text { gangster re- } \\
\text { venge film }\end{array}$ \\
\hline Slovakia 2.0 & 10.04 .2014 & 918 & 13.50 & social drama \\
\hline Eva Nová & 19.11 .2015 & 9,313 & 41.76 & social drama \\
\hline Koza & 10.09 .2015 & 2,940 & 16.99 & social drama \\
\hline The Cleaner & 15.10 .2015 & 2,077 & 11.54 & social drama \\
\hline Pirko & 6.10 .2016 & 21,724 & 25.86 & social drama \\
\hline Stanko & 14.04 .2016 & 1,395 & 8.25 & $\begin{array}{c}\text { social } \\
\text { road-movie }\end{array}$ \\
\hline Red Captain & 10.03.2016 & 87,224 & 45.81 & political thriller \\
\hline
\end{tabular}

As a matter of fact, Candidate was the result of the AVF rare attempt at dramaturgical shaping of Slovak cinema - the Minimal programme aimed at supporting low-budget genre films. The programme was created in order to follow up the coincidence of the fund's early days with the onset of two new trends within the Slovak live-action film: low-budget genre film and social drama. Whereas the former was meant to appeal to a wider range of domestic film-goers, but was often produced in not fully professional conditions, the latter was meant to in- 
crease competitiveness of Slovak cinema at international film festivals but had low domestic audience numbers. In fact, the audience attendance of social dramas was relatively low compared with the attendance of "hypermodern-lifestyle" films from the beginning of the millennium. The critical response to one of the first social dramas, Lištičky (Foxes, 2009) by Mira Fornay, was even comparably negative as the response to the "urban lifestyle films" - despite the fact this was one of the internationally most acclaimed Slovak co-productions of its time. Only around 2012, following the obvious festival successes of some socially attentive Slovak films, Slovak critics started to construct the genre of Slovak social drama, and it was not until then that they almost univocally started to praise its "artistic" qualities. ${ }^{18}$ Since Candidate was the only one of the three films supported at the time by the Minimal programme that was relatively successful in this respect, it was not surprising that similar dramaturgical ambitions of the Slovak AVF didn't reappear. $^{19}$

\section{"Empty" anaesthetics and distanced acting}

What exactly does this replacement of urban lifestyle films by the construction of social drama by the Slovak film community mean? Taking aside more obvious pragmatic, but also generational reasons, ${ }^{20}$ I would like to show that social drama, together with popular genre films, was actually recognized as a genre that had the potential to overcome something that, among others, Šmatlák described as one of the most important deficiencies in Slovak cinema of the previous decade: a kind of "coldness" that doesn't affect any part of the cinematic communication chain specifically.

In a way, Šmatlák’s 2003 review can be seen as a kind of negative prescription, according to which a film shouldn't be "so so deeply preoccupied with itself that it [wouldn't] establish any relationships", it shouldn't be "so deprived of emotions that it [would be] utterly heartless", it shouldn't create "a reality without facts, stories or interpretations". In short, it shouldn't be so "cool XXL", like its millennial predecessors.

${ }^{18}$ M. Urban, Identita autora. Príbehy, sociálne reprezentácie a naratívne Self v slovenskej kinematografii v rokoch 2012-2017, VEDA - Ústav divadelnej a filmovej vedy SAV, Bratislava 2017, pp. 74-77.

19 The other two films supported by Minimal programme are a gangster revenge film Babie leto (Indian Summer, dir. Gejza Dezorz, 2013) and a social road-movie Stanko (dir. Rast'o Boroš, 2015).

20 The most profound analyses of Slovak social drama - as a cycle of mostly generational films, often connected with persona of screenwriter Marek Leščák — were delivered by Katarína Mišíková, see e.g. K. Mišíková, "Hl’adanie žánru v súčasnom slovenskom hranom filme”, [in:] Nový slovenský film, eds. K. Mišíková, M. Ferenčuhová, Bratislava 2015, pp. 9-36. 
In his Ästhetisches Denken (Aesthetic Thinking, 1990), Wolfgang Welsch defines "coolness" ("this new virtue of the 1980s") as a symptom of a new "anaesthetics". It includes "indifference and desensitisation even at an intoxicatingly high level of stimuli. Aesthetic animation takes place in a form of narcosis, in both meanings of the word: as an intoxication, as well as numbness". ${ }^{21}$

The Slovak translation of the quoted collection of Wolfgang Welsch's articles was published in 1993 and there is some evidence of its immediate impact on the practice of Slovak theatrical criticism. Already in 1996, critic Anna Grusková used Welsch's concept of anaesthetics and his definition of coolness in her article on recent tendencies in new Slovak drama. ${ }^{22}$ A theatre theorist Elena Knopová now argues that Grusková's term, "coolness drama", was broadly adopted by both Slovak and Czech theatre critics and scholars as a kind of local version of what Aleks Sierz called "in-yer-face theatre". ${ }^{23}$ According to Knopová, ${ }^{24}$ Slovak theatrologists, quickly replaced the term by its confusing and rather inappropriate abbreviation. "Cool drama" became a common term used to denote the contemporary (post-)dramatic tendencies in theatre, including those that employed cruelty, vulgarity, controversy - often in sharp contrast to the dominant meaning of the word "cool". 25

We can only speculate on the connections between Šmatlák's more appropriate understanding of the word in the context of the hypermodern lifestyle film, the practice of Slovak theatre critics ${ }^{26}$ and the translation of Welsch's book. Nevertheless, Welsch's anaesthetics - as well as the "cool" version of emotionality of Lehmann's postdramatic theatre ${ }^{27}$ — expresses well what Slovak film critics intuitively rejected, identifying with emptiness and coldness of the urban lifestyle films. With the exception of Juraj Malíček, most of the domestic critical response to urban lifestyle films was negative, especially with regard to the supposed "coolness" of their appearance. The themes of emptiness and coldness appear as dominant especially in reviews of Šindelka's It Will Stay Between Us. If Šmatlák's abovementioned review placed emphasis on the emptiness and coldness of its

${ }^{21}$ Quotations are from the Slovak translation of Welsch's book: W. Welsch, Estetické myslenie, transl. L. Kiczko, Bratislava 1993, p. 12.

22 A. Grusková, "Dramatika coolness", Divadlo v medzičase 1, 1996, p. 9.

${ }^{23}$ A. Sierz, In-Yer-Face Theatre: British Drama Today, London 2001.

${ }^{24}$ E. Knopová, Svet kontroverznej drámy, Bratislava 2010, p. 25.

${ }^{25}$ Ibid., p. 28. Knopová also points out the distinction between what Sierz meant by his term "in-yer-face drama" (which is usually "hot", and its "cooler" version is perceived by Sierz also as more conservative) and Hans-Thies Lehmann's understanding of the term "cool" as one of the many forms of emotionality within postdramatic theatre.

26 The term "cool drama" is used also in Hungary and Poland, together with alternative terms such as "new brutalism" (Knopová, op. cit., p. 24). In general, the terms "cool/ coolness drama" are used only in some Eastern European countries (Czech Republic, Hungary, Poland, Macedonia and Slovakia), but Slovakia is the only country in which "cool drama" was used predominantly, not along its various alternatives (ibid., p. 28).

${ }^{27}$ H.-T. Lehmann, Postdramatic Theatre, London-New York 2006. 
plot, other reviewers highlighted also its poor or ungainly acting. According to one of the reviewers, ${ }^{28}$ the film's coldness is equally the result of its hypermodern settings and its poor-quality cast. Several other millennial films were criticized for awkward and ungainly acting, too. To a certain extent, this was a result of a loss of continuity with fully effective and publicly supported cinema: not only were screenplays underdeveloped, often featuring poor dramaturgy or dialogues, but film directors and actors, especially those of new generations, also lacked more systematic knowledge on specifically filmic acting skills. This was one of many results of the collapse of the film industry after 1991 when, according to Martin Šmatlák, also many film professions ceased to exist. ${ }^{29}$ In some cases, "bad acting" was also the result of low-budget casting of non-actors, often coming from director's own circle of friends (e.g. Hana a jej bratia - Hannah and Her Brothers, dir. Vladimír Adásek, 2001, or Vadi nevadi - Truth or Dare, dir. Eva Borušovičová, 2001) or being a result of "experimental" marketing with casting local celebrities from show business (It Will Stay Between Us).

Nevertheless, the seemingly incoherent acting conceptions did share one important feature: in most of the millennial urban films, actors were often encouraged to adopt some aspects of what we can call distanced acting. Even the title of one of two films that started the trend of urban lifestyle films, Truth or Dare, refers to cultivation of the emotional state that can be described by the popular slang word "cool". The film's characters try not to express their emotions and the narrative contains a leitmotif of "truth or dare" game, through which they test their limits of pain and taste preferences.

Acting, posing, or role-playing are also themes of most of the millennial urban films: the heroine of Two Syllables Behind, a film that starts with the alienation effect of dubbing a Latino soap opera, works as a dubbing-actress and even takes the role of Red Riding Hood in a short commercial. Role-playing is also one of dominant themes of the first two urban lifestyle films, Adásek's autofiction debut on transgender identity Hannah and Her Brothers and Borušovičová's criminal romance Truth or Dare. Both role-playing and posing are thematized as parts of consumerist attitude to life and love in It Will Stay Between or Polčas rozpadu (Half-Life, dir. Vlado Fischer, 2007). On the other hand, some films emphasize the contrast between the glamour of television or advertising industry and "real life" troubles (i.e. wars in less developed countries, or the collapse of modern nuclear family): Two Syllables Behind, Truth or Dare, Ženy môjho muža (My Husband's Women, dir. Ivan Vojnár, 2009).

In a way, these themes themselves lead to a distanced attitude to the world and to a neglect of an essentialist conception of reality. Nevertheless, distanced acting (in both meanings of the word) was, together with emotional distantiation

${ }^{28}$ This time, the review was written for the Czecho-Slovak magazine Mosty: M. Ščepka, “Opravný pokus neúspešného debutanta”, Mosty 23, 2003, p. 15.

29 M. Šmatlák, "Hl'adanie vlastnej cesty", p. 138. 
of characters and ignoring the traditional realistic principles of Stanislavsky method, characteristic also for early films by Martin Šulík, the emblematic Slovak film autheur of the 1990s. Yet Šulík's version of distantiation stems from an existential feeling of uprootedness and is often confronted with inhuman calmness of idyllic landscapes or still-life shots. Since urban lifestyle films were often seen as an opposition to the cinema of Šlík and his followers, it is perhaps not so surprising that Martin Šmatlák explicitly identifies only two fore-runners of this trend: namely, Štefan Semjan's On the Beautiful Blue Danube (and Roman Petrenko's Hazard (1995).${ }^{30}$ But On the Beautiful Blue Danube, even if it is a direct source of inspiration for Truth or Dare, refers to completely different sensibilities of the 1960s and 1980s: to the concept of carnivalesque foolishness of the Slovak New Wave cinema (especially of early films by Juraj Jakubisko and Elo Havetta), and at the same time to the culture of swinging London or the cinema of Jim Jarmush. The behaviour of its protagonists is theatrical and excessive on purpose, they even identify themselves as "herci" - which literally means "actors" (with the roots of the word meaning also a "game" — "hra"). The film's emphasis on improvisation in acting forms a different notion of distantiation when compared with minimalist expression and emotional unapproachableness in early films of Šulík, but also when compared to millennial "coolness". When it comes to actors and their specific expression, urban lifestyle films of the new millennium have much more in common with Šulík than with Semjan.

The disapproval of emotional coldness of millennial urban films, which appears as the dominant approach to this trend in domestic film criticism of early 2000 s, nevertheless results in a misleading idea of (dis)continuities within the dominant sensibility of Slovak cinema. Thus, it was also possible to almost completely replace urban lifestyle films with other genres equally based on the rhetoric of emotional distantiation, like social drama. Both trends - the social drama and the millennial lifestyle film - have in common the emotional reservedness of characters, coldness of interpersonal relationships, and replacement of the characters' emotions with specific compositional solutions of image, editing and sound.

Nevertheless, most Slovak millennial urban films are dominated by what we can call an adult perspective typical for classical rationalism and Cartesian spatial logic, which, according to Merleau-Ponty, denies the existence of embodied knowledge and reduces the possibilities of art to convey the complex world of perception. ${ }^{31}$ This logic is anticipated already in Semjan's debut On the Beautiful Blue Danube, shot almost exclusively in long and American shots that emphasize the distance between the observed and the observer. ${ }^{32}$ On the other hand, there

${ }^{30}$ Ibid., p. 145.

${ }^{31}$ M. Merleau-Ponty, The World of Perception, London 2004.

32 The film's plot - a fake theft of an Andy Warhol picture from the exhibition in Slovak National Gallery - offers a rich source of art-historical inspiration for understanding distantiation as an ironical approach to human ability of knowing the truth. Even in this sense Semjan acts in 
are many exceptions that confirm this rule. In Two Syllables Behind, an autobiographical debut by Katarína Šulajová, childish imagination and enchantment with the world are put in sharp contrast with the advertising anaesthetics employed in most of the shots. Yet, the images that suggest the heroine's imagination and enchantment are presented as sources of her weakness, of her inability to adapt to the contemporary, hypermodern world. What is more, even the shots that are meant to mediate the dreamlike qualities of heroine's perception are conceived in line with the kind of "colonial" logic of representation and relationship of mastery between the observer and the world. The heroine, confronted with her feelings of inferiority while visiting Paris, imagines herself as a Japanese geisha, albeit in real life she tries to act as a self-confident tourist or even coloniser (e.g. in relation to a Chinese immigrant shoemaker).

The anaesthetic, polished "cool" images inspired by flourishing advertising industry, became dominant in most of the millennial urban films, and were replaced by more tactile images only in later hip-hop inspired films by Jakub Kroner (Bratislavafilm, 2009 and Lóve, 2011). ${ }^{33}$ Speaking more generally, the whole of postsocialist Slovak cinema usually avoids exploring the synesthetic or tactile qualities of film image. It does not attempt to achieve what the film scholar Martine Beugnet perceives as putting an emphasis on physicality and sensuality of the film image, ${ }^{34}$ or what Merleau-Ponty calls "reawakening of the world of perception". 35 The recent adaptation of a deeply sensual book on children's perception, Piata lod'(Little Harbour, dir. Iveta Grófová, 2017), ${ }^{36}$ is, symptomatically enough, the first consistent exception from this rule, soon followed by Juraj Lehotskýs family drama Nina (2017). Both films are not only emphasizing the world of (children's) perception and/or imagination, they also stem from some socially attentive motifs that Katarína Mišíková recognizes as specific for what she calls the cycle of Slovak social dramas. ${ }^{37}$ If we observe this cycle more closely, we can see that

opposition to Šulík who likes to confront his distanced images of people with indexical images and close-ups of still-lifes.

${ }^{33}$ Nevertheless, the openness and ambiguity of the extremely multivalent term "cool" is illustrated by the fact that some scholars associate this term precisely with later urban films like Bratislavafilm or Vel'ký rešpekt (Big Respect, dir. Viktor Csudai, 2008), stemming more from various youth subclutures than from mainstream cultural patterns. See e.g. M. Boszorád, "Cool ako výrazovýá kvalita slovenských filmových projektov súčasnosti”, [in:] Současný český a slovenský film. Pluralita estetických, kulturnich a ideových koncepti̊, eds. L. Ptáček. R. Veselá, Olomouc 2010, pp. 35-41.

${ }^{34}$ M. Beugnet, Cinema and Sensation: French Film and the Art of Transgression, Edinburgh 2012.

${ }^{35}$ M. Merleau-Ponty, op. cit., p. 69.

${ }^{36}$ M. Kompaníková, Piata lod', Bratislava 2012.

37 According to Mišíková, the cycle of the socially attentive Slovak films with common motifs and methods are undergoing a process of genrification (as understood by Rick Altman). Thus, they gradually start to be recognized and defined as a specific genre. See: K. Mišíková, "Hl'adanie žánru...", pp. 35-36. 
already some of Slovak social dramas try to provide haptic qualities: for example, Eva Nová (dir. Marko Škop, 2015) continuously puts an emphasis on facial skin structures of the main actress, while in Môj pes Killer (My Dog Killer, dir. Mira Fornay, 2013) placing the camera behind the top of the protagonist's head also strengthens the feeling of an almost touchable closeness. These methods are not unusual, they are just new in the context of postsocialist Slovak cinema. The cycle of Slovak social dramas systematically tries to overcome the dominance of an unbiased and distanced perspective of the rational, adult (and most often white male) observer, ${ }^{38}$ and does this also by a specific choice of its main protagonists. The hero of Koza is a Romani man, the heroine of Eva Nová is an ageing woman, and protagonists of most of other Slovak social dramas are young adolescents from the peripheries of society, ${ }^{39}$ or members of ethnic minorities (e.g. Hungarians in Ďakujem, dobre - Fine, Thanks, dir. Mátyás Prikler, 2013; or Slovak Hungarians migrating to Latvia in György Kristóf's Out, 2017).

This also leads to a more profound solution to the problem of imperfect acting, disapproved of by critics of Slovak urban lifestyle films. In social dramas, the problem is quite simply solved by radical reduction of dialogues. Even though casting predominantly features non-actors, their facial expression remains monotonous and restrainted (with exception of the film star Emília Vášáryová playing the role of the ageing actress Eva Nová in eponymous Marko Škop's film). What is even more important: social dramas offer a different concept of coldness that remains related to moderate acting, but not to the impact on the audience. Inspired by the minimalist tendencies of European festival cinema, contemporary Slovak social dramas transform the concept of hypermodern emptiness of posing and role-playing into an existential emptiness usually motivated by country's economic decline, or by the idea of families in crisis. However, the most important aspect of Slovak social dramas is that they offer a new range of stylistic devices that stand in sharp opposition to the (an)aesthetics of distantiation typical of previous periods of Slovak cinema. They bring into question the adult, (white) male perspective while focusing on subordinated, uprooted, socially disadvantaged subjects, very often children, women or adolescents.

Thus, the anaesthetic of "coolness", prescriptively condemned by the first critiques of millennial lifestyle films, finds itself transformed into social drama's focus on the emptiness and coldness of the contemporary postsocialist desert. The additional value that social dramas bring to the dominant sensibility of Slovak

38 This description of the dominant type of the observer in classical representational arts is used by Martine Beugnet who tries to broaden up Merleau-Ponty's definition of the subject of Carthesian space logic. See: M. Beugnet, op. cit., p. 4.

39 Starting with Foxes, Dom (The House, dir. Zuzana Liová, 2011), Cigán (Gypsy, dir. Martin Šulík, 2011), and continuing with $A z ̌$ do mesta Aš (Made in Ash, dir. Iveta Grófová, 2012), Môj pes Killer (My Dog Killer, dir. Mira Fornay, 2013), Zázrak (The Miracle, dir. Juraj Lehotský, 2013), Deti (Children, dir. Jaroslav Vojtek, 2014), Pirko (dir. Lucia and Petr Klein Svoboda, 2016). 
cinema is, in the end, their ability to touch upon universally human, existential topics while following the specific sensibility typical for the so-called (European) festival minimalism. This, nevertheless, also means a tendency to transform overall postmodern feelings of alienation and coldness by questioning the mainstream, rational, "Carthesian" perception.

\section{Bibliography}

\section{Secondary sources}

Beugnet M., Cinema and Sensation: French Film and the Art of Transgression, Edinburgh University Press, Edinburgh 2012.

Boszorád M., "Cool ako výrazovýá kvalita slovenských filmových projektov súčasnosti”, [in:] Současný český a slovenský film. Pluralita estetických, kulturních a ideových koncepti̊, eds.

L. Ptáček, R. Veselá, Univerzita Palackého v Olomouci, Olomouc 2010, pp. 35-41.

Bourdieu P., On Television, The New Press, New York 1998.

Dudková J., Slovenský film v ére transkulturality, Drewo a srd. and VŠMU, Bratislava 2011.

Grusková A., "Dramatika coolness", Divadlo v medzičase 1, 1996, p. 9.

Hečko M., Havran M., Kandidát. Denníky z odpočúvania, Inaque, Bratislava 2012.

Kacarová D., "V kríze sú tvorcovia, nie slovenský film", Národná obroda 32, 2005, p. 13.

Knopová E., Svet kontroverznej drámy, VEDA, Bratislava 2010.

Kompaníková M., Piata lod', Koloman Kertész Bagala, Bratislava 2012.

Lehmann H.-T., Postdramatic Theatre, transl. K. Jürs-Munby, Routledge, London-New York 2006. Malíček J.,"Pop po domácky”, Slovo 9, 2004, p. 16.

Merleau-Ponty M., The World of Perception, Routledge, London 2004.

Mišíková K., "Hl'adanie žánru v súčasnom slovenskom hranom filme”, [in:] Nový slovenský film, eds. K. Mišíková, M. Ferenčuhová, Vysoká škola múzických umení v Bratislave, Bratislava 2015, pp. 9-36.

Mišíková K., "The real story: Indexing strategies of Slovak social film dramas", [in:] Transformation Processes in Post-Socialist Screen Media, eds. J. Dudková, K. Mišíková, Vysoká škola múzických umení v Bratislave and Ústav divadelnej a filmovej vedy SAV, Bratislava 2016.

Moscovici S., "Foreword", [in:] Health and Illness: A Social Psychological Analysis, ed. C. Herzlich, Academic Press, Oxford 1973.

Moscovici S., "The phenomenon of social representations", [in:] Social Representations: Explorations in Social Psychology, ed. G. Duveen, New York University Press, New York 2001, pp. $18-77$.

Ščepka M., "Opravný pokus neúspešného debutanta”, Mosty 23, 2003, p. 15.

Sierz A., In-Yer-Face Theatre: British Drama Today, Faber, London 2001.

Šmatlák M., “Cool XXL”, Domino forum 42, 2003, p. 26.

Šmatlák M., "Hl'adanie vlastnej cesty", Kino-Ikon 1, 2008, pp. 135-147.

Šmatlák M., "The Slovak Audiovisual Fund: A brief history of prolonged time," [in:] Transformation Processes in Post-Socialist Screen Media, eds. J. Dudková, K. Mišíková, Vysoká škola múzických umení v Bratislave and Ústav divadelnej a filmovej vedy SAV, Bratislava 2016.

Urban M., Identita autora. Príbehy, sociálne reprezentácie a naratívne Self v slovenskej kinematografii v rokoch 2012-2017, VEDA - Ústav divadelnej a filmovej vedy SAV, Bratislava 2017.

Urban M., Sociálne reprezentácie v diskurze slovenských filmových profesionálov v rokoch 2012 2014 (unpublished dissertation: Univerzita Konštantína Filozofa v Nitre, 2016). 
Urban M., Identita autora. Príbehy, sociálne reprezentácie a narativne Self v slovenskej kinematografii v rokoch 2012-2017, VEDA and Ústav divadelnej a filmovej vedy SAV, Bratislava 2017. Welsch W., Estetické myslenie, transl. L. Kiczko, Archa, Bratislava 1993.

\section{Online sources}

http://www.cedslovakia.eu/clanky/sprava-o-stave-slovenskej-audiovizie-v-roku (accessed:5.12.2017).

\section{Filmography}

Až do mesta Aš [Made in Ash], dir. I. Grófová, Slovakia-Czech Republic 2012.

Babie leto [Indian Summer], dir. G. Dezorz, Slovakia-Czech Republic 2013.

Bratislavafilm, dir. J. Kroner, Slovakia 2009.

Cigán [Gypsy], dir. M. Šulík, Slovakia-Czech Republic 2011.

Červený kapitán [Red Captain], dir. M. Kollár, Slovakia-Czech Republic-Poland 2016.

Čistič [The Cleaner], dir. P. Bebjak, Slovakia 2015.

Deti [Children], dir. J. Vojtek, Slovakia-Czech Republic 2014.

Dom [The House], dir. Z. Liová, Slovakia-Czech Republic 2011.

Ďakujem, dobre [Fine, Thanks], dir. M. Prikler, Slovakia 2013.

Eva Nová, dir. M. Škop, Slovakia-Czech Republic 2015.

Hana a jej bratia [Hannah and Her Brothers], dir. V. Adásek, Slovakia 2001.

Hazard, dir. R. Petrenko, Slovakia-Czech Republic 1995.

Kandidát [Candidate], dir. J. Karásek, Slovakia-Czech Republic 2013.

Koza, dir. I. Ostrochovský, Slovakia-Czech Republic 2015.

Lištičky [Foxes], dir. M. Fornay, Ireland-Czech Republic-Slovakia 2009.

Lóve, dir. J. Kroner, Slovakia-Czech Republic 2011.

Môj pes Killer [My Dog Killer], dir. M. Fornay, Slovakia-Czech Republic 2013.

Na krásnom modrom Dunaji [On the Beautiful Blue Danube], dir. S. Semjan, Slovakia 1994.

Nebo, peklo ... zem [Heaven, Hell ... Earth], dir. L. Siváková, Slovakia 2009.

Nina, dir. J. Lehotský, Slovakia-Czech Republic 2017.

Dve slabiky pozadu [Two Syllables Behind], dir. K. Šulajová, Slovakia-Czech Republic 2004.

Out, dir. G. Kristóf, Slovakia-France-Hungary-Czech Republic 2017.

Piata lod' [Little Harbour], dir. I. Grófová, Slovakia-Czech Republic 2017.

Pirko, dir. L. Klein Svoboda, P. Svoboda, Czech Republic-Slovakia 2016.

Polčas rozpadu [Half-Life], dir. V. Fischer, Slovakia 2007.

Slovensko 2.0, dir. O. Rudavský, M. Šulík, V. Č́anyová, Z. Liová, M. Suchý, J. Herz, M. Jelok,

P. Krištúfek, I. Grófová, P. Kerekes, Slovakia 2014.

Slnečný štát [The City of the Sun], dir. M. Šulík, Czech Republic-Slovakia 2005.

Stanko, dir. R. Boroš, Slovakia 2015.

Tango s komármi [Mosquito's Tango], dir. M. Luther, Slovakia-Czech Republic 2009.

Tigre v meste [Tigers in the City], dir. J. Krasnohorský, Slovakia 2012.

Vadi nevadí [Truth or Dare], dir. E. Borušovičová, Slovakia 2001.

Vel'ký rešpekt [Big Respect], dir. V. Csudai, Slovakia 2008.

V̌̌etko alebo nič [All or Nothing], dir. M. Ferencová, Slovakia-Czech Republic-Poland 2017. 
Zázrak [The Miracle], dir. J. Lehotský, Slovakia-Czech Republic 2013.

Zostane to medzi nami [It Will Stay between Us], dir. M. Šindelka, Slovakia-Czech Republic 2003.

Ženy môjho muža [My Husband's Women], dir. I. Vojnár, Slovakia-Czech Republic-Hungary 2009.

\section{"Cool XXL": Slovak millennial films in the context of post-socialist sensibility (of Slovak cinema)}

\section{Summary}

The article stems from social representations of coolness in Slovak cinema of the beginning of the new millenium and examines how these representations blur or deform the idea of continuities and discontinuities with regard to the sensibility of postsocialist Slovak cinema. The article points out the critical response of Slovak urban lifestyle films from the beginning of the new millenium and shows the transformation of its own idea of anaesthetical coolness into "festival" dramaturgy of the cycle of Slovak social dramas appearing after 2009. 